\title{
Helminth parasites in feces of Antillean manatees Trichechus manatus manatus (Sirenia:Trichechidae) in Mexico: Gulf of Mexico and Caribbean
} Helmintos parásitos en heces de manatí Antillano Trichechus manatus manatus (Sirenia: Tricheachidae) en México:
Golfo de México y Caribe Arturo Hernández-Olascoaga ${ }^{1}$, León David Olivera-Gómez¹ and Benjamín Morales-Vela²

${ }^{1}$ División Académica de Ciencias Biológicas, Universidad Juárez Autónoma de Tabasco. Km. 0.5 carretera Villahermosa-Cárdenas, entronque a Bosques de Saloya, Villahermosa, Tabasco, 86039. México ${ }^{2}$ El Colegio de la Frontera Sur, Unidad Chetumal. Avenida Centenario Km. 5.5, Chetumal, Quintana Roo, 77040. México e-mail: leon_olivera@yahoo.com.mx

Recibido: 23 de marzo de 2016.

Aceptado: 23 de octubre de 2016.

Hernández-Olascoaga A., L. D. Olivera-Gómez and B. Morales-Vela. 2017. Helminth parasites in feces of Antillean manatees Trichechus manatus manatus (Sirenia:Trichechidae) in Mexico: Gulf of Mexico and Caribbean. Hidrobiológica 27 (1): 39-44. D0I: 10.24275/uam/izt/dcbs/hidro/2017v27n1/0livera

\begin{abstract}
Background. Low helminth diversity has been reported in West Indian manatees (Trichechus manatus). Most studies were conducted on the Florida sub species $T$. $m$. latirostris in subtropical environments, therefore limited information is available for the tropical Antillean subspecies T. m. manatus. In Mexico, there are apparently two population units of $T . m$. manatus. Goals. The objective of this study was to survey the presence and prevalence of helminth parasite eggs in the feces of T. m. manatus from the Gulf of Mexico (GM) and Caribbean coasts (CAR) of Mexico. Methods. We used 31 fecal samples collected from GM $(n=22)$ and CAR $(n=9)$, from 2005 to 2008. Feces were fixed and preserved in $70 \%$ ethanol until analysis. Both floatation and sedimentation techniques were used. Helminth eggs were identified using specialized literature and graphic catalogs. Results. We found parasite eggs in $61.2 \%$ of feces; all samples from CAR had helminths. We documented eggs from five helminths: three digenetic (Chiorchis fabaceus, C. groschafti, and Pulmonicola cochleotre$\mathrm{ma}$ ) and two Nematoda (Heterocheilus tunicatus and Ascarididae gen. sp.). Two species were found exclusively from GM, one exclusively from CAR, and two species were common to both locales. Conclusions. Diversity was consistently low in the samples. Four of the species found are common to Florida and Caribbean islands and one is a new registry for this host. Future examination of manatee carcasses could confirm the presence of adult helminth species for new registries for this host.
\end{abstract}

Key words: Helminth eggs, parasites, sirenians, tropical México.

\section{RESUMEN}

Antecedentes. En el manatí del Caribe (Trichechus manatus) se reporta baja diversidad de helmintos y la mayoría de los estudios se han realizado en la subespecie de Florida ( $T$. $m$. latirostris) en ambientes subtropicales, por lo que existe poca información para la subespecie Antillana (T. m. manatus). En México, al parecer existen dos unidades poblacionales de manatí Antillano. Objetivos. El objetivo de este estudio fue determinar la presencia y prevalencia de huevos de helmintos parásitos en heces de T. m. manatus del Golfo de México (GM) y la costa del Caribe Mexicano (CAR). Métodos. Se utilizaron muestras de heces de 31 manatíes, tanto de GM $(n=22)$ como del CAR $(n=9)$, de 2005 a 2008. Las heces se fijaron y preservaron en alcohol etílico al 70\% hasta su análisis. Las técnicas utilizadas fueron de flotación y sedimentación. Los huevos de helmintos se identificaron apoyándose en literatura especializada y catálogos gráficos. Resultados. En el $61.2 \%$ de las heces analizadas se encontraron parásitos, todas las muestras de CAR contenían parásitos. Se registraron huevos de cinco especies de helmintos: tres digéneos (Chiorchis fabaceus, C. groschafti y Pulmonicola cochleotrema) y dos nemátodos (Heterocheilus tunicatus y Ascarididae gen. sp.). Dos especies fueron exclusivas para GM, una para CAR y dos fueron comunes para ambas áreas. Conclusiones. La diversidad fue consistentemente baja en las muestras. Cuatro especies fueron comunes con Florida y las islas del Caribe y una es nuevo registro para este hospedero. Futuros estudios parasitológicos en cadáveres frescos confirmarán la existencia de helmintos adultos para los nuevos registros en este hospedero.

Palabras clave: Huevos de helmintos, parásitos, sirenios, trópico de México. 


\section{INTRODUCTION}

The main objective of studying parasites of wild mammals is to determine their effect on the health and ecology of populations (Samuel et al., 2001). In manatees (Sirenia: Trichaechidae), however, studies of parasites are relatively scarce (Marsh et al., 2012). The Florida manatee (Trichechus manatus latirostris, Harlan 1824), in subtropical latitudes, has been the most studied (Bando et al., 2014), because many dead manatees are recovered and available for examination. Some studies have been conducted on Antillean manatees (Trichechus m. manatus, Linnaeus 1758) in Cuba (Coy-Otero, 1989), Puerto Rico (MignucciGiannoni et al., 1999a,b), and the Dominican Republic (Colón-Llavina et al., 2009). Only six species of helminth parasites have been reported in T. m. manatus: five digenetic and one Nematoda (Marsh et al., 2012). Searching for eggs in feces is a viable and non-invasive technique to describe helminth diversity in manatees (Bando et al., 2014).

The species Trichechus m.manatus is listed as endangered, both internationally (Self-Sullivan \& Mignucci-Giannoni, 2008) and in Mexico (SEMARNAT, 2010). The largest manatee population in Mexico inhabits the southern region of the Gulf of Mexico, within the states of Tabasco, northern Chiapas, southern Campeche (Colmenero \& Hoz, 1986), and the Caribbean coast of Quintana Roo (Morales-Vela \& Olivera-Gómez, 1997; Morales-Vela et al., 2000). Recently, Nourisson et al. (2011) demonstrated genetic evidence of discreteness between these two populations in Mexico. In this study, we examined the presence and prevalence of helminth eggs in the feces of $T$. m. manatus in Mexico, from populations of the Gulf of Mexico (inland population, inhabiting freshwater systems) and the Caribbean (inhabiting mostly brackish and marine water).

\section{MATERIALS AND METHODS}

From 2005 to 2008, we collected fecal samples from 31 T. m. manatus in different localities in the Southern Gulf of Mexico (GM) and Caribbean coasts (CAR) in Mexico (Fig. 1). We analyzed 22 samples from 10 localities in the state of Tabasco in GM and 9 samples from two localities of the state of Quintana Roo in CAR (Table 1, Fig. 1). Within GM, samples came from two river basins, Grijalva (GV) and Usumacinta (USU) and within CAR, samples came from two coastal bays, Bahía de Chetumal (BCH) and Bahía de Ascensión (BA). All CAR samples and nine from GM were taken from manatees captured for health-assessment projects, immediately after the individual excreted during handling. For the other samples, one was taken from a rescued animal, four came from necropsies, four were from animals in captivity, and four samples were from fresh feces found floating on waterways. Fecal samples collected in dead stranded animals were taken from the latest newly formed stools with a greenish consistency, directly from the large intestine. Collected feces were placed in sterile containers with a capacity of $100 \mathrm{ml}$, with a tight lid and fixed and stored in $70 \%$ ethylic alcohol until analyses.

A qualitative flotation technique (saline saturated solution) was used to isolate eggs from stool samples. This technique involves a solution with a higher density than the eggs in the sample. We used 2 to $5 \mathrm{~g}$ of homogenized stool sample and mixed it with $20 \mathrm{ml}$ of saline saturated solution in a stirring device and filtered same through a mesh to a test tube until forming a convex meniscus. We then gently placed a coverslip on top of the test tube. After 20 min we carefully lifted off the coverslip from the tube and placed it on a microscope slide to observe it. We also used the sedimentation (formalin-ether) technique where the

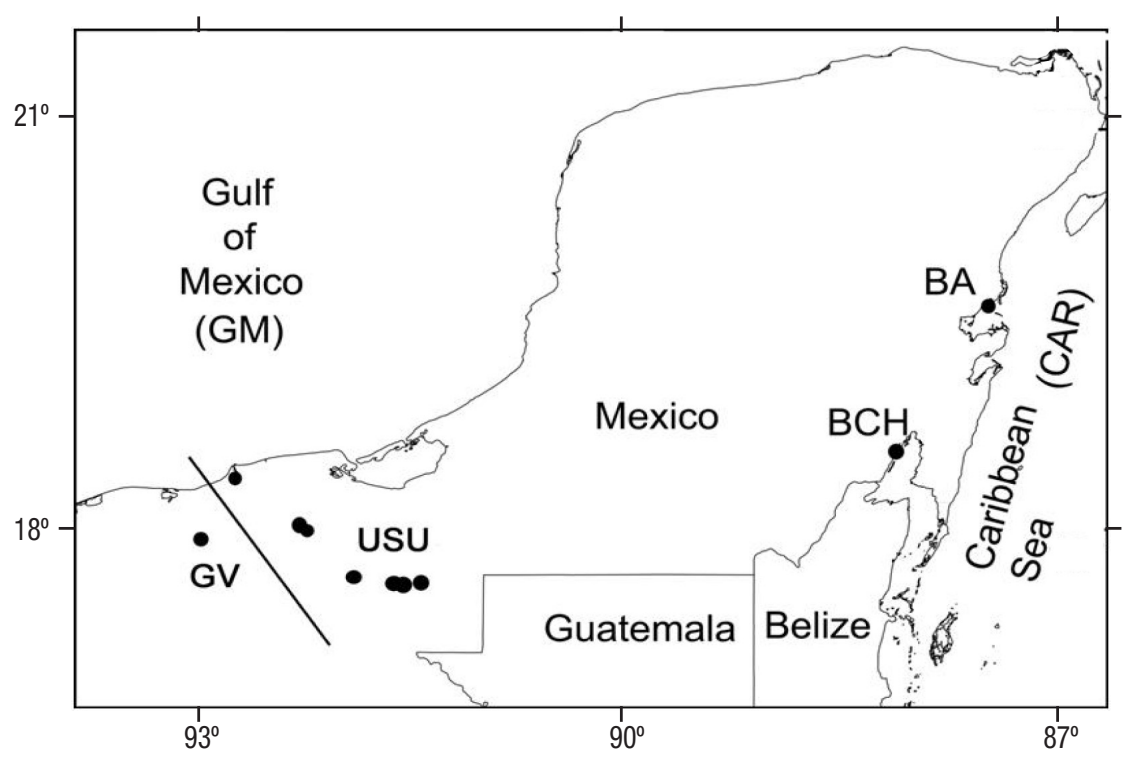

Figure 1. Study area at Southeastern Mexico. Points are sampling localities within the Gulf of Mexico (GM) and Caribbean coasts (CAR). Subregions of GM are the Usumacinta River Basin (USU) and Grijalva River Basin (GV). Subregions of CAR are Bahía de Chetumal (BCH) and Bahía de Ascensión (BA). 
eggs are not distorted but rather deposited by gravity at the bottom of the container. We used 2 to $5 \mathrm{~g}$ of stool sample in $10 \mathrm{ml}$ of $10 \%$ formalin, filtered through a mesh. We added $6 \mathrm{ml}$ of the suspension in $3 \mathrm{ml}$ of ether in a centrifuge tube and mixed at $3000 \mathrm{rpm}$ for $3 \mathrm{~m}$. Then we decanted the final solution and an aliquot was taken with a Pasteur pipette and placed on a microscope slide to observe it (Lamothe-Argumedo, 1997; Cruz-Reyes \& Camargo-Camargo, 2001; Foreyt, 2001).

Eggs were identified under a microscope, using specialized literature and graphic catalogs (Travassos et al., 1969; Dailey et al., 1988; Coy-Otero, 1989; Foreyt, 2001; Bando et al., 2014) and measured to $\mu \mathrm{m}$ with a ruled ocular. Microphotographs of representatives were taken with a digital camera. Empiric prevalence was calculated following the concepts of Bush et al. (1997), i.e., the number of hosts infected with one or more species of parasites divided by the number of hosts examined. Qualitative similitude within the sampling region was estimated by cluster analysis, using the UPGMA algorithm and Jaccard's index (Moreno, 2001), with MVSP software 3.22 (Kovach Computing Services, Kovach, 2010).

\section{RESULTS}

Five species of helminths were identified, three digenetic and two nematode. Digenea: Chiorchis fabaceus (Diesing, 1938) Fischoider, 1901 $(\mathrm{n}=12$, Fig. $2 \mathrm{~A})$, a large ovoid, almost elliptical, egg, $169.0 \times 101.3$ (148-180 x 90-120), a thin membrane covering the egg, operculated side, barrel shaped with symmetrical walls. Chiorchis groschafti Otero, 1989 ( $n=18$, Fig. 2B) a smaller egg, 97.5 x 69.5 (80-108 x 6071), same characteristics of $C$. fabaceus. Pulmonicola cochleotrema
(Travassos\&Vogelsang, 1931) Batron\& Blair, 2005, ( $n=23$, Fig. 2C) very small eggs, ovoid, thin covered, $18.6 \times 10.2$ (17-22 x 10-12), with a filament extended on each pole, the operculum is located on the base of the filament of the wider pole.

Nematodes, Heterocheilus tunicatus Diesing, 1839 ( $n=24$, Fig. 2D) a reddish egg, slightly ovoid with a thick, rough wall, $160.4 \times 149.1$ (150-170 x 140-160), content does not fill the full eggshell. Ascarididae gen. sp. Baird, 1853 ( $n=1$, Fig. 2E) an ovoid egg, compressed on both poles, $50 \times 30$, thick and smooth reddish wall.

From the 31 individuals samples, $19(61.2 \%)$ were infected by at least one helminth. Ten animals from GM (45.4\%) and the whole CAR sample (100\%) were infected. Four helminth species were found in GM samples and three from CAR. Among the species found, in the CAR sample, $C$. groschafti had the highest prevalence $(66.6 \%)$, followed by H. tunicatus (44.4\%) and P. cochleotrema (33.3\%) (Fig. 3). In GM sample, $P$. cochleotrema had the highest prevalence $(22.7 \%)$ followed by C. fabaceus (18.1\%) and H. tunicatus (13.6\%) (Fig. 3). Parasites in the individual samples varied from 0 to two species (mean $=0.83$ species/ sample). Seven samples had two species $(22.5 \%)$, twelve samples had one species $(38.7 \%)$, and twelve samples were free $(38.7 \%)$ of parasites.

In terms of similarity, the generated cluster separated GM and CAR regions at an index ca. 0.30 (Fig. 4). Subregions in CAR (BA and BCH) were more similar than those in GM (GV and USU) (Fig. 4). Three species were shared by both populations, two were found only in GM samples, and one species only in CAR samples (Fig. 3). The species with higher prevalence differed among populations.
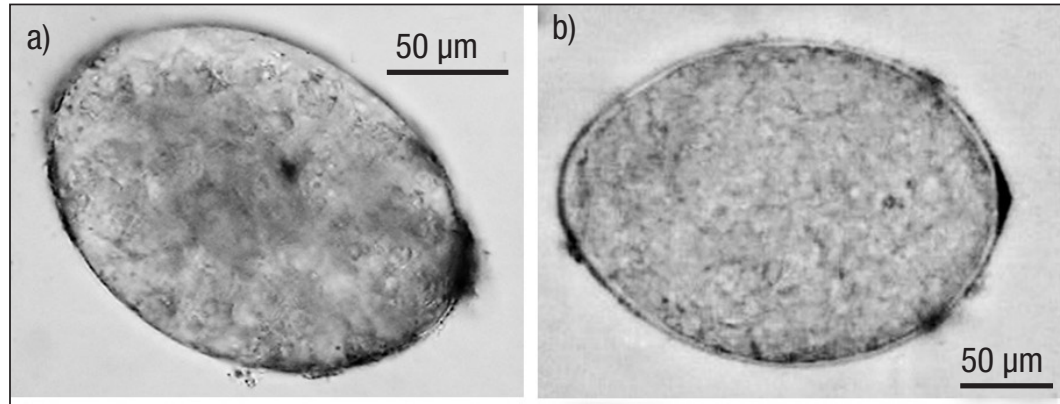

c)

d)

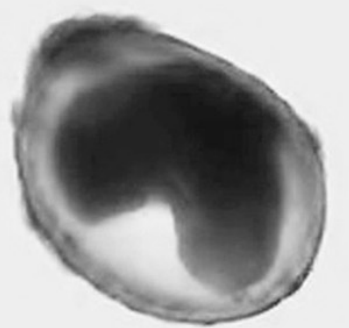

$50 \mu \mathrm{m}$

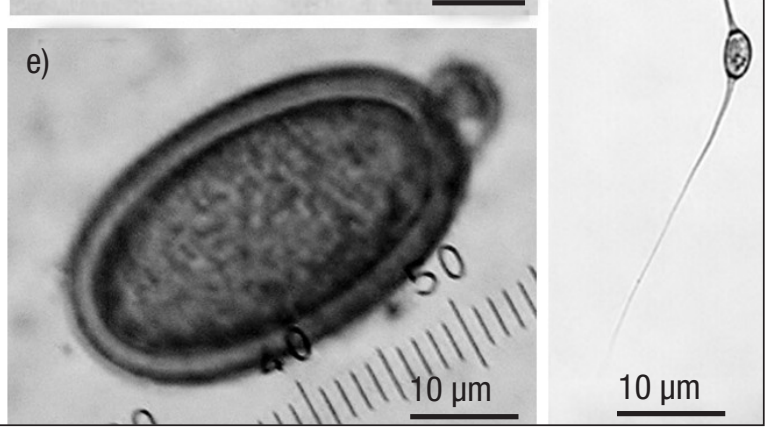

Figures 2a-e. Helminth eggs found in feces of Trichechus manatus manatus: a) Chiorchis fabaceus (169.0x101.3 $\mu \mathrm{m})$. b) Chiorchis groschafti (97.5 x $69.5 \mu \mathrm{m})$.

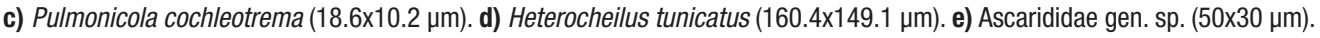




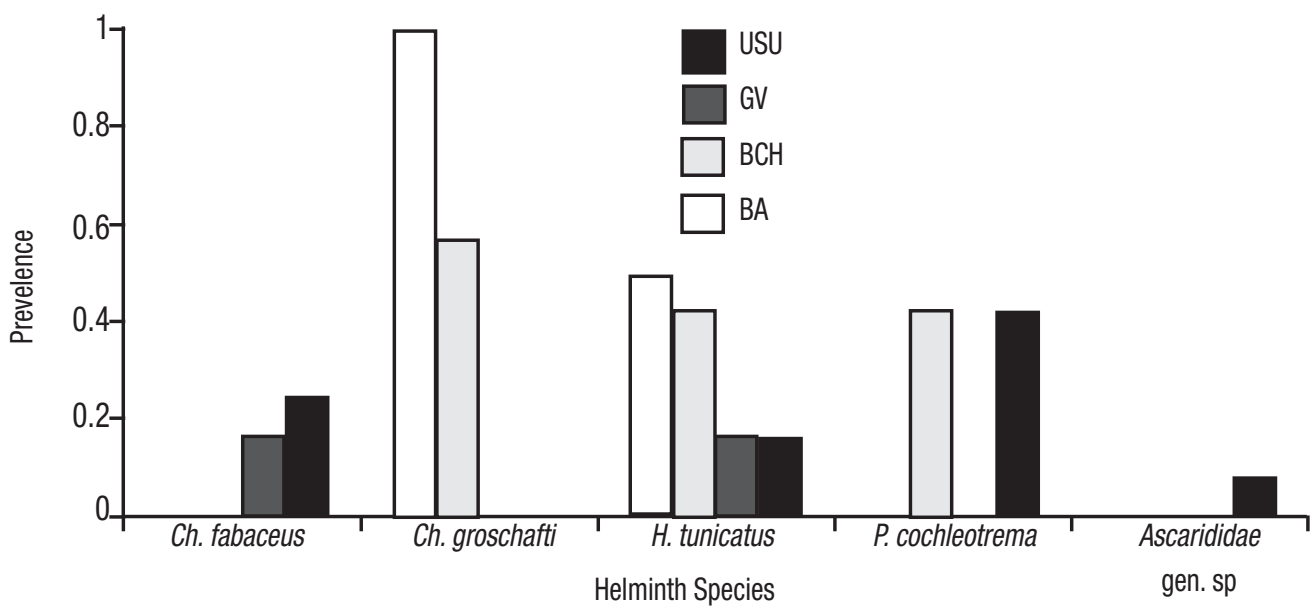

Figure 3. Prevalences of five species of helminth eggs found in feces of Trichechus manatus manatus in México on subregions of the Gulf of Mexico (Usumacinta River basin (USU), Grijalva River basin (GV), Caribbean Coasts (Bahia de Chetumal (BCH) and Bahia de Ascension (BA).

\section{DISCUSSION}

Helminth parasite diversity in $T$. m. manatus is consistently low. There are reports of only six species in the literature (Marsh et al., 2012). This could be a result of small samples, limited research, and a focus on feces or content of the digestive track, but also due to the habits of the species, whose distribution tends toward freshwater environments, while its herbivorous diet is mainly fibrous plants. As a comparison, 22 species of helminths are reported for the dugong Dugong dugon (Müller, 1776) (Sirenia: Dugongidae) (Beck \& Forrester, 1988), which is a marine species. Four of the species found in this study, $C$. fabaceus, C. groschafti, $P$. cochleotrema, and $H$. tunicatus were reported as adult parasites of dead manatees in Florida (Beck \& Forrester, 1988), Cuba (Coy-Otero, 1989), Puerto Rico (Mignucci-Giannoni et al., 1999a), the Dominican Republic (Mignucci-Giannoni et al., 1999b), Brazil (Carvalho et al., 2009), and Mexico (González-Solís \& Vidal-Martínez, 2004).

Bando et al. (2014) described eggs from six helminth species in $T$. m. latirostris: H. tunicatus; $C$. fabaceus; $C$. groschafti; P. cochleotrema;

GV

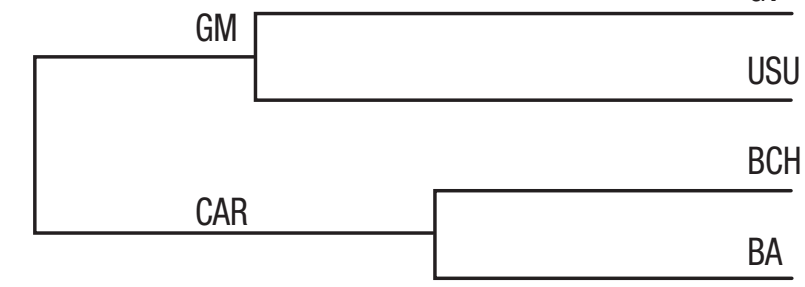

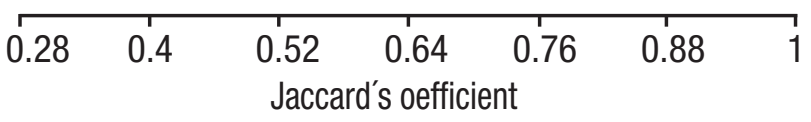

Figure 4. Similarity of subregions of the Gulf of Mexico (GM) and Caribean coasts (CAR) of Mexico, based on the egg prevalences of five species of parasite helminth in feces of Trichechus manatus manatus. The method used was UPGMA.
Moniligerum blairi Dailey, Vogelbein \& Forrester, 1988, and Nudacotyle undicola Dailey, Vogelbein \& Forrester, 1988. The eggs we analyzed coincided with descriptions and measurements taken by Bando et al. (2014) for C. fabaceus $169 \times 110$ (160.4-178.2 x 98-118.8), C. groschafti 98x70 (93.5-104.5 x 49.5-74.8), P. cochleotrema 22.4x10.5 (20.9-24.2 $x 8.8-11)$, and $H$. tunicatus $154 \times 155$ (124.7-190.1 x 127.7-193.1).

Members of the Paramphistomidae family are often found in $T . m$. manatus, C.fabaceus, and C. groschafti in Florida, Cuba, Puerto Rico, the Dominican Republic, and the east coast of the Yucatan Peninsula. C. fabaceus had been reported in the three species of the Trichechidae family: T. manatus, T. inunguis (Natterer, 1883), and T. senegalensis (Link, 1795) (Marsh et al., 2012). Individuals of Chiorchis sp. inhabit the digestive tract, mainly in the colon and cecum. Their life cycle has not yet been studied, but it is thought that manatees ingest them by consuming small snails with cercarias (digenea larvae) that are on the aquatic plants they feed on (Raga et al., 2009).

Digenea $P$. cochleotrema from the Opisthotrematidae family is described from nostrils, trachea, and bronchi of manatees (Marsh et al., 2012). This species is registered from T. m. latirostris in Florida (Beck \& Forrester, 1988) and from T. m. manatus in México, Puerto Rico, the Dominican Republic, and Brazil (Mignucci-Giannoni et al., 1990b; González-Solís \& Vidal-Martínez, 2004; Colon-Llavina et al., 2009; Carvalho et al., 2009)

The ascarid nematode $H$. tunicatus belongs to the Heterocheilidae subfamily, which is common in aquatic reptiles (especially in crocodiles) and in sirenian mammals (Anderson, 2000). These adult helminths have been recorded from Florida (Beck \& Forrester 1988), Puerto Rico (Mignucci-Gianonni et al., 1999a), the Dominican Republic (MignucciGianonni et al., 1999b), and the eastern Yucatan Peninsula (GonzálezSolís \& Vidal-Martínez, 2004), in great numbers throughout the digestive tract, mainly in the stomach. Sanvicente (2005) reported eggs of $H$. tunicatus in feces found along the Caribbean coasts of Mexico (Quintana Roo) and from the Gulf of Mexico (Tabasco and Campeche). Jueco (1977) previously suggested that manatees feed on the intermediate hosts when consuming vegetation. 
Eggs of the parasites that we attribute solely to the Ascarididae gen. sp. family have an unknown origin. In the Gulf of Mexico localities, domestic animals like cows, horses, dogs, and cats are often found along the waterways and lakes; many lakes and freshwater systems are lentic (low energy) and receive wastes from urban and rural communities, which could favor some species of parasites.

Necropsies of manatees from the Caribbean coast of Mexico, where manatees inhabit coastal environments, often found greater numbers of nematodes and digenea in the digestive tract. However, in the Gulf of Mexico, where manatees are found almost exclusively within freshwater, the parasite load is low and just one adult species had been registered, the $C$. fabaceus (Hernández-Olascoaga \& Olivera-Gómez, pers. com.) digenea.

Other reported species of digenea, Nudacotyleundicola and Moniliger umblairi or coccidea, Eimeria manatus Upton, Odell, Bossart \& Walsh, 1989 and E. nodulosa Upton, Odell, Bossart \& Walsh, 1989 (Beck \& Forrester, 1988; Upton et al., 1989) were not observed as eggs or as other forms in our study. The sample size could influence the diversity found, since more samples were analyzed for the GM population. However, this study supports evidence that manatee helminth fauna is not diverse (Raga et al., 2009) compared to other aquatic mammals like cetacean or pinnipeds (Foreyt, 2001; Raga et al., 2009).

The differences of helminth fauna between the two regions are in keeping with the genetic information of the limited movements of individuals between the regions (Nourisson et al., 2011) and indicate that different ecological pressures act upon the populations. These differences also support the idea that both populations should be managed separately. Despite their low diversity, future studies on local helminth differences that used larger sample numbers could generate information on their habitat.

\section{ACKNOWLEDGEMENTS}

We would like to thank Serapio López Jiménez, José Domínguez-Alpizar, David González-Solís, and Cruz Ulin-Izquierdo for their comments and suggestions regarding this analysis. We also wish to thank Leticia García-Magaña for her comments and granting us access to the parasitology laboratory at the Academic Division of Biological Sciences at the Universidad Juárez Autónoma de Tabasco. We also give our thanks to Mauro Sanvicente-López for his bibliographic support. Samples were collected with support from the following projects: SEMARNAT2004-C01-385, PROMEP/103.5/04/2582, and SEMARNAT/CONACYT 2002-C01-1128 (Quintana Ro0). The following federal permits were used: SEMARNAT/DGVS703144, 04513, 03670/06 and 03675/07.

\section{REFERENCES}

Anderson, R. C. 2000. Nematode parasites of vertebrates: Their Development and Transmission, 2nd. Ed. CABI Publishing, $635 \mathrm{p}$.

Bando, M., I. V. Larkin, S. D. Wright \& E. C. Greiner. 2014. Diagnostic stages of the parasites of the Florida manatee, Trichechus manatus latirostris. Journal of Parasitology 100 (1): 133-138. D0I: 10.1645/13206.1
Beck, C. A. \& D. J. Forrester. 1988. Helminths of the Florida manatee, Trichechus manatus latirostris, with a discussion and summary of the parasites of sirenians. Journal of Parasitology 74: 628-637.

Bush, A. O., K. D. Lafferty, J. M. Lotz \& A. W.Shostak. 1997. Parasitology meets ecology on its own terms: Margolis et al. revisited. Journal of Parasitology 83 (4): 575-583.

Carvalho, V. L., A. D. Oliveira de Meirelles, M. R. M. Alves, D. C. Colares, M. C. V. Moraes \& C. M. B. Leal. 2009. Ocurrence of Pulmonicola cochleotrema (syn. Cochleotrema cochleotrema) (Digenea: Opisthotrematidae) in Antillean manatees (Trichechus manatus manatus) in Brazil. Latin American Journal of Aquatic Mammals 7 (1-2): 47-52. DOI: $10.5597 /$ lajam00132

Colmenero, L. C. \& M .E. Hoz. 1986. Distribución de los manatíes, situación y conservación en México. Anales del Instituto de Biología, Universidad Nacional Autónoma de México, Serie Zoología 56 (3): 955-1020.

Colon-Llavina, M. M., A. A. Mignucci-Giannoni, S. Mattiucci, M. Paoletti, G. NASCETTI \& E. E. WiLLIAMS. 2009. Additional records of metazoan parasites from Caribbean marine mammals, including genetically identified anisakid nematodes. Parasitology Research 105: 1239-1252. DOI: 10.1007/s00436-009-1544-4

Coy-Otero, A.1989. Una nueva especie de trematodo del género Chiorchis (Diplodiscidae), un parásito del manatí Trichechus manatus (Sirenia) de Cuba. Poeyana 378: 1-4.

Cruz-Reyes, A. \& B. Camargo-Camargo. 2001. Glosario de términos en Parasitología y Ciencias Afines. Instituto de Biología, UNAM. México. $347 \mathrm{p}$.

Dalley, M. D., W. Vogelbein \& D. J. Forrester. 1988. Moniliger umblairi $\mathrm{n}$. g., n. sp. and Nudacotyle undicola n. sp. (Trematoda: Digenea) from the West Indian Manatee, Trichechus manatus. Systematic Parasitology 11: 159-163

Foreyt, J. W. 2001. Veterinary Parasitology: Reference Manual, Fifth edition. lowa State Press. 230 p.

González-Solís, D. \& V. M. Vidal-Martínez. 2004. Helmintos parásitos de manatíes y cetáceos varados en la costa de la península de Yucatán, México. Memorias del XVI Congreso Nacional de Parasitología. Tlaxcala, México del 11 al 16 de octubre.

JueCo, N. L. 1977. The trematode Paradujardinia halicoris in the sea cow in Phillipines. Journal of Biology 6: 257-262.

Kovach, W. L. 2010. MVSP - A MultiVariate Statistical Package for Windows, ver. 3.2. Kovach Computing Services, Pentraeth, Wales, U.K.

Lamothe-Argumedo, R. A. 1997. Manual de técnicas para preparar y estudiar los parasitos de animales silvestres. AGT Editor. México. 43 p.

MarSh, H., T. J. O'SheA \& J. E. Reynolds III. 2011. Ecology and Conservation of the Sirenia: Dugongs and Manatees. Cambridge University Press. $521 \mathrm{p}$.

Mignucci-Giannoni, A. A., C. A. Beck, R. A. Montoya-Ospina \& E. H. Williams JR. 1999a. Parasites and commensals of the West Indian manatee from Puerto Rico. Journal of the Helminthological Society of Washington 66 (1): 67-69. 
Mignucci-Giannoni, A. A., E. H. Willams JR., G. M. Toyos-González, J. PérezPadilla, M. A., Rodríguez-López, M. B. Vega-Guerra \& M. Ventura-GonzáLEZ. 1999b. Helminths from a stranded manatee in the Dominican Republic. Veterinary Parasitology 81: 69-71.

Morales-Vela, B. \& L. D. Olivera-Gómez. 1997. Distribución del manatí (Trichechus manatus) en la costa norte y centro-norte del estado de Quintana Roo, México. Anales del Instituto de Biología, Universidad Nacional Autónoma de México, Serie Zoología 68 (1): 153-164.

Morales-Vela, B., L. D. Olivera-Gómez, J. E. Reynolds III \& G. B. Rathbun. 2000. Distribution and habitat use by manatees (Trichechus manatus manatus) in Belize and Chetumal Bay, Mexico. Biological Conservation 95: 67-75. DOI: 10.1016/S0006-3207(00)00009-4

Morales-Vela, B., J. A. Padilla-Saldivar \& M. Sanvicente-López. 2002. Mortandad de manatíes en la Bahía de Chetumal y riesgos actuales. In: Rosado-May, F.J., R. Romero-May \& A. de Jesús-Navarrete (Eds.).Contribuciones de la ciencia al manejo costero integrado de la Bahía de Chetumal y su área de influencia. Universidad de Quintana Roo. Chetumal, Q. Roo, México. pp. 67-72.

Moreno, C. E. 2001. Métodos para medir la biodiversidad. M \& T - Manuales y Tesis SEA, vol.1 Zaragoza. $84 \mathrm{p}$.

Nourisson, C., B. Morales-Vela, J. A. Padilla-Saldivar, K. P. Tucker, A. M. Clark, L. D. Olivera-Gómez, R. Bonde \& P. McGuire. 2011. Evidence of two genetic clusters of manatees with low genetic diversity in Mexico and implications for their conservation. Genetica 139: 833842. DOI: 10.1007/s10709-011-9583-Z
Raga, J. A., M. Fernández, J. A. Balbuena \& F. J. Aznar. 2009. Parasites. In: W. F. Perrin, B. Wursig \& J. G. M. Thewissen (Eds.) Encyclopedia of Marine Mammals. 2nd ed. Academic Press, pp. 821-829.

Samuel, W. M., M. J. Pybus \& A. A. Kocan. 2001.Parasitic Diseases of Wild Mammals. Second Edition. lowa State University Press. 570 p.

Sanvicente, M. L. 2005. Diagnóstico de agentes parasitarios en el manatí del Caribe (Trichechus manatus) en la región del sureste de México. Tesis de Maestría en Ciencias en Recursos Naturales y Desarrollo Rural. El Colegio de la Frontera Sur, Chetumal, Quintana Roo, México. $51 \mathrm{p}$.

Self-Sullivan, C. \& A. A. Mignucci-Giannoni. 2008. Trichechus manatus ssp. manatus. The IUCN Red List of Threatened Species 2008:e. T22105A9359161. Available online at: http://dx.doi.org/10.2305/ IUCN.UK.2008.RLTS.T22105A9359161.en. (Downloaded January 20, 2016).

Semarnat (Secretaría de Medio Ambiente y Recursos Naturales). 2010. N0M-059 Diario Oficial de la Federación. Secretaría de Medio Ambiente y Recursos Naturales. 30 de diciembre de 2010.

Travassos, J. F., T. Freitas \& A. Kohn. 1969. Trematódeos do Brasil. Memorias del Instituto Oswaldo Cruz. 67: 625-626.

Upton, S. J., D. K. Odell, G. D. Bossart \& M. T. Walsh. 1989. Description of the oocysts of two new species of Eimeria (Apicomplexa: Eimeriidae) from the Florida manatee, Trichechus manatus (Sirenia: Trichechidae). Journal of Protozoology 36 (1): 87-90. 